\title{
Phantasmagorical Research: How Theory Becomes Art in the Work of Roland Barthes
}

\author{
Kathrin Busch
}

\begin{abstract}
:
In his latest statements, Roland Barthes imagines a becoming-art of his thinking. But rather than switching from a theoretical to a literary form he reflects his desire of a new writing as the beginning of a new thinking, which leads him to another knowledge. His intended new form is ambivalent. It results from indecision between essay and novel, critique and narration and thereby detects a hidden dynamic of thinking: Its phantasmatic sources and emotional conditions reveal an affective knowledge, in which the pathos leads to the truth and gains the significance of a philosophem.
\end{abstract}

I consider Roland Barthes an author who does artistic research. He occupies a threshold between art and science, which he opens up in his last lectures at the Collège de France with astonishing precision and honesty and-in the very last lecture - turns it into the object of his research. ${ }^{1}$ Unreservedly he offers his listeners insight into what one can call the process of theory becoming art. He explains how he does his research-in the knowledge that this ethnology of his own process of writing and thinking brings something to light that obviously deviates from the image that is usually created of the way that a scientist works. His descriptions are valuable because they portray how thought unfolds in the aesthetic and thus create access to the processes, issues, and fundamentals of artistic research.

Crucially, the process of theory becoming art delineated in the late texts does not mean that Barthes becomes a littérateur. His process of 'becoming' remains unfinished, not only because his death abruptly put an end to his enterprise. He thought it was important to linger in this interim space. He sets up a

1 Besides his "Lecture in Inauguration of the Chair of Literary Semiology" (1977), mention must be made of his three lecture courses at the Collège de France, which were published posthumously in 2002 and 2003: How to Live Together: Novelistic Simulations of Some Everyday Spaces (1976-1977), The Neutral (1977-1978), and The Preparation of the Novel (1978-1979 and 1979-1980). 
state of uncertainty between art and research, writing 'as if' he were trying to produce literature. This 'as if' represents a space where a phantasm-or, more precisely, the fantasy of being a writer-exists. In the imagination his writing gains space but proceeds conceptually in this fictional space. Out of this arises a conceptual fantasy or a phantasmagorical way of thinking that engages in theory-fiction.

According to Gilles Deleuze and Félix Guattari, this process of theory becoming art can be understood as an unfinished transition, in which one sort of identification does not turn into another, but identification and its ascriptions are held at arm's length and neutralised in favour of an as-yet-undetermined process of 'becoming other'. What arises out of this indecision? For Barthes: a third form. The invention of a new way of writing, in which theory is given an artistic quality. ${ }^{2}$ Instead of switching from science to literature, and writing stories instead of theoretical texts, Barthes's writing springs from the indecision over treatise and novel, interpretation and story, critique and narrative. As he says, one can react in writing to any event in two ways: first, by interpreting or commenting on it, or, second, by retelling it and spinning a thread. Barthes blends the registers: he creates linguistic figures that function analytically and develops fictions about abstract ideas. ${ }^{3}$ Barthes combines the "writer's perspective" with an "interest in research, by telling about what has been researched, by spreading it, making it seem ambiguous, fragmented," and figured. ${ }^{4}$ In this way, he suspends the binary opposites and formulates an attack on a way of thinking that functions with dualisms. Barthes cuts across other Western oppositions: like no other author he presents thought as affective and,

2 While the signature of this new kind of writing marks all of Barthes's later works, he presented his ideas about it mostly in two texts: in his very last lecture course, Roland Barthes, The Preparation of the Novel: Lecture Courses and Seminars at the College de France (1978-1979 and 1979-1980) (2003), translated by Kate Briggs. New York: Columbia University Press, 2011, and in a short essay going back to a lecture held in 1978 titled "Longtemps, je me suis couché de bonne heure ..." (cf. Roland Barthes, The Rustle of Language (1984), translated by Richard Howard. Oxford: Basil Blackwell, 1986, pp. 277-290). The "literary" Barthes is an object of interest also in literary theory, where his late texts are considered "Romanesque experiments" (Karin Peters, "Einleitung: Pourquoi j'aime Barthes, oder: Philologie als Liebe," in: Angela Oster/Karin Peters, eds., Jenseits der Zeichen: Roland Barthes und die Widerspenstigkeit des Realen, Munich: Fink 2012, pp. 11-31: here p. 12).

3 His theory is already fiction, of the kind that does not affect the substance, which remains committed to the truth, but the kind of expression, the practice of articulation. (See Tzvetan Todorov, "Der letzte Barthes" (1981), translated by Joseph Vogl, in: Hans-Horst Henschen, ed., Roland Barthes. Munich: Boer, 1988, pp. 129-137: here pp. 130-131).

4 Hanns-Josef Ortheil, "Nachwort," in: Roland Barthes, Variations sur l'écriture. Variationen über die Schrift (2002), translated by Hans-Horst Henschen. Mainz: DVB, 2006, pp. 195-217: here p. 206. 
even more, he envisions reason sublimated by the erotic. This idea is strong: reason itself must be sublimated. ${ }^{5}$ When Barthes reverses all the usual notions about the cultivation of instinctual drives, affect becomes a means to increase the profundity of thought and carefully refine it. ${ }^{6}$ In categorising concepts, which always goes hand in hand with hierarchisation, dominance is exercised. Barthes's criticism of rationality, which is the foundation of his ideas, does not drive him away from knowledge into a world of pure, immediate sensation, but towards a kind of thought touched upon by affect, towards theory permeated by sensibility.

\section{The Affectivity of Thought}

Everything begins with pathos, or affect-with something that forces one to think. Thinking is not an activity, not a voluntary act, but something suffered, a passion. It is triggered by what has been experienced. It begins involuntarily. "Thought is nothing without something that forces and does violence to it."7 Not: I research, but: I am seized by something that drives me towards knowledge. This process resists a methodic plan. Barthes follows Nietzsche's distinction between method and culture, which Deleuze has already addressed. ${ }^{8}$ The conventional scientific method assumes deliberate decisions; it is a purposeful activity. ${ }^{9}$ In contrast, the culture or cultivation of ideas presents "a violence undergone by thought," ${ }^{10}$ a formation of thought by forces and violence that one either suffers or succumbs to. These forces determine the sensitive, embodied, or ingrained formations of thought. They leave behind traces and inscriptions in the thinker. Their yields are inseparable from the textures of the self. This affects the researching subject, which becomes different during the

See Roland Barthes, "F.B.," in: The Rustle of Language (1984), translated by Richard Howard. Oxford: Basil Blackwell, 1986, pp. 223-232: here p. 227.

6 The process of refining and nuancing is the theme of second lecture course at the Collége de France, Roland Barthes, The Neutral: Lecture Course at the Collège de France (1977-1978) (2002), translated by Rosalind Kraus and Denis Hollier. New York, NY: Columbia University Press, 2005 .

This is how Deleuze describes it in: Gilles Deleuze, Proust and the Signs (1964), translated by Richard Howard. London: The Athlone Press, 200o, p. 96.

8 See Gilles Deleuze, Nietzsche and Philosophy (1962), translated by Hugh Tomlinson. New York: Columbia University Press, 1983, p. 103.

9 See Roland Barthes, How to Live Together: Novelistic Simulations of Some Everyday Spaces. Notes for a Lecture Course and Seminar (1976-1977) (2002), translated by Kate Briggs, New York: Columbia University Press, 2013, p. 3 .

Deleuze (1983), Nietzsche, p. 108. 
process of research. This non-methodical, yet self-cultivating form of research includes the subconscious. It can be guided by what the subject does not know about himself, and by what is solely effective as a force or counter-force in the research.

According to Barthes, then, research raises a kind of knowledge whose unconscious origins and affective conditions are not denied but utilised. It follows an affective form of cognition, in which desire opens up a path to a truth that is as singular as experience shapes it. Supported by the capacity to be affected by means of "sensitivity ... affectivity, sentiment,"1l thought occurs within a heightened sense of differentiation and an extraordinary lucidity. Affects, not concepts, comprise the guideline for thought. Barthes's unusual idea is that consciousness functions as a drug in this emotive research. Like the notion of sublimating reason through affect, this idea also runs counter to the common understanding. This is not about drugs manipulating consciousness. Barthes considers the hypersensitive consciousness that is devoted to aesthetic thought as a drug itself, to the extent that it intensifies affect and presents "the vivid 'sensibility."'12 Excessive awareness develops a total receptivity to sensory stimuli through which one ultimately becomes what one feels. ${ }^{13}$ In this state of hyperesthesia, affect and consciousness become one. Barthes calls this seemingly paradoxical liaison "affective clarity" -instead of attesting a dark or nebulous force feelings, they are permeated by presence of mind.

\section{Phantasmagorical Research}

Barthes demonstrates this affective thought in his lectures and seminars at the Collège de France. In conceiving each one, he begins with a fantasy that haunts him, and he uses it as a guideline for his research, first, by attempting to find a word for it. ${ }^{14}$ There is a need, therefore, for a connecting factor. Barthes calls it a magic "word that transmuted the fantasy into a field of knowledge"15 and is opened up to research. He then takes the word, which corresponds to a "stubborn affect,"16 and promenades it through a number of readings. This word

\footnotetext{
11 Barthes (2005), The Neutral, p. 77.

12 Barthes (2005), The Neutral, p. 96.

13 See Barthes (2005), The Neutral, p. 99.

14 Barthes spelled out three phantasms: the idiorrhythmic (in How to Live Together), neutralisation (in The Neutral), and finally, the idea of the novel (in The Preparation of the Novel).

15 Barthes (2013), How to Live Together, p. 7.

16 Barthes (2005), The Neutral, p. 8.
} 
unlocks a wide range of source materials and theories related to his desire. It is as if the concept is carried out along "a 'network of readings.'."17 The "forces by which the fantasy attains to or opens out onto culture: don't act in a straightforward manner, are subject to unforeseen tensions." ${ }^{18}$ He explicitly speaks of "an aesthetic of work (a value ruled out by science)"19 insofar as he does not systematically work through the field of knowledge, but only recurs to books that reveal an allure for him. So he merely uses the kind of literature that "crystallizes" something in him, thanks to the affect, and in this way, he allows the texts he works with to "think in [him]self." 20 Texts have an impact to which he makes himself receptive and sensitive, and which he allows to become virulent in his thoughts. He does not deal with, analyse, or evaluate them. Freeing himself "from all will-to-possess," 21 he allows the others' thoughts to germinate inside himself. Out of this germination, he develops figures of thought in which ideas take on vivid form. They, too, have powers that cannot be methodologically appropriated by science.

\section{Figures of Thought}

In the process, the field of knowledge becomes fragmented and organised into aesthetic "figures." ${ }^{22}$ Barthes varies each theme his imagination provides him with, "instead of articulating it with a view to find a final meaning." ${ }^{33}$ Recurring to serial music, he identifies figural thought as a way of thinking in variations, rather than arguing in logical terms. The theme threads like a motif through the contingent of serialised figures. Their figurativeness is understood to be literal. Barthes's figures are fragments of thoughts that have a "face," an "air," an "expression." ${ }^{24}$ They are more than merely rhetorical tropes of figurative or imagistic speech in metaphors or metonymy. They are figural in the original sense of figura, which Erich Auerbach defines as Gestalt. ${ }^{25}$ Figura originally

17 Barthes (2005), The Neutral, p. 9.

18 Barthes (2013), How to Live Together, p. 9.

19 Barthes (2005), The Neutral, p. 22.

20 Ibid.

21 Roland Barthes, "Lecture in Inauguration of the Chair of Literary Semiology. Collège de France, January 7, 1977," translated by Richard Howard, in: October 8 (1979), pp. 3-16: here p. 4.

22 Barthes (2005), The Neutral, pp. 10-11.

23 Barthes (2005), The Neutral, p. 10.

24 Ibid.

25 See Erich Auerbach, "Figura," (1938), in: Scenes from the Drama of European Literature, translated by Ralph Manheim. Minneapolis, MN: University of Minnesota Press, 1984, pp. $11-76$. 
meant plastic form, not fixed or statue-like, but as "something living, dynamic, incomplete, and playful." ${ }^{26}$ In contrast to forma, figura accentuates the sensory manifestation or external form in its dynamic dimension. It is the moving, transforming form, which is why the word is also used to describe the unstable fantasy and dream figure. ${ }^{27}$ Later, in early Christian literature, the term is employed to characterise "real prophecy."28 Figura is appropriate here precisely because it accentuates sensory, descriptive specifics. Figura means signs in the form of a real, physical embodiment, which predict something that will come.

Aesthetic thought, as Barthes conceived of it, is also figurative thought: it creates something that is embodied, and hence, figures that are endowed with life and expressivity. The figures presented are visual riddles, or, as he calls them, "rebus drawings." ${ }^{29}$ In them the figured thought becomes gradually apparent; it is formed in the developing figure. It determines the formation of thought and drives out the imaginary. It makes up the figures that lend life to a thought. They have their own dynamics, a historical signature; they are born and die, go astray or atrophy. As something figured, knowledge itself takes on sensitive qualities when figures attract other figures, awaken images, or reinforce feelings. Each figure begins to think for itself and becomes a quasi-creature, itself receptive to meaning.

\section{Powerlessness}

In emphasising the aesthetic, it remains important not to contrast it with the political. On the contrary, literary texts are eminently political insofar as they cause a shift within the language, which is permeated by the compulsions of typecasting and ideologies. Here, Barthes follows Michel Foucault's discourse, his analytical position, which has shown-primarily in The Order of the Discourse ${ }^{30}$ - how power and knowledge intertwine. In artistic writings, in

26 Auerbach (1984), Figura, p. 12.

27 See Auerbach (1984), Figura, pp. 13-17.

28 Thus, Christian teachings mention events from the Old Testament that foreshadow future events from the New Testament. What is crucial here is the reality of the occurrences; the figures from the Old Testament are not considered allegories, despite their prophetic meaning. Rather, they are "concrete historical facts." Auerbach (1984), Figura, p. 30.

29 Barthes (2005), The Neutral, p. 10.

30 See Michel Foucault, "The Order of Discourse" (1971), translated by Ian McLeod, in: Robert Young, ed., A Post-Structuralist Reader. Boston et al.: Routledge \& Kegan Paul, 1981, pp. $5^{1-78 .}$ 
contrast, the "forces of freedom" are at work in the "labor of displacement," which they "bring to bear upon the language." 31 The political lies in the "responsibility of form,"32 in the issue of speaking "not according to the law,"33 and in resisting the standardising modes of speech that exercise domination.

In his inaugural lecture, Barthes reveals the processes that neutralise the power relations of language and are supposed to provide space for the indirectness and latency of a singular, affected thought. He counts "loosening"34 [French: dépris] as one of his basic operations to combat the hardening, hegemonic discourse. In a later lecture, Barthes discusses the process that is connected to this initially abstract-seeming concept as a figure of thought: "to unthread" [parfiler] means picking something apart. ${ }^{35}$ Traditionally, the French word parfiler describes a process of removing the gold threads woven into cloth by picking them out. Unthreading is a method of fraying: the fabric is dissolved, thread-by-thread, to separate out the valuable material. What has been separated out is the nuance, the non-indifferent, whatever is of concern. For Barthes, nuance is not only required for thinking but also an ethical agenda: life according to the nuance. Writing watches over it. As artistic research, literature is supposed to pluck out precious nuances.

So, instead of recording, understanding, or securing knowledge, the fundamental task of artistic research is to dissolve the discourse, to fray knowledge, subvert truths - meaning, to fragment (instead of systematising) in writing and to digress in one's elucidation (instead of arguing in a straight line). Both procedures or forms - fragment and drift—are basic forms of essayistic writing. The essay is at odds with the orders of art or science. The boundaries are different, not at the level of the abilities — sensuality versus reason — but of the different forms of discourse. In science, knowledge is a statement; in writing essays or in doing artistic research, knowledge is formulated as an expressive event. In it, the situation of the utterance is articulated with an "immense halo of implications, of effects, of echoes, of turns, returns, and degrees". ${ }^{36}$ As an expressive event that has detaches itself from the constative power of language, it does not censor the researcher's subjectivity. The expression of one's own singularity and the nuanced treatment of affects and fantasies means nothing more than worrying about one's imagination, "on which depends

\footnotetext{
$31 \quad$ Barthes (1979), Lecture, p. 6.

32 Ibid.

33 Barthes (1979), Lecture, p. 9.

34 Barthes (1979), Lecture, p. 15.

35 Barthes (2005), The Neutral, p. 11.

36 Barthes (1979), Lecture, p. 7 .
} 
the vital thing we are used to call 'happiness." ${ }^{37}$ Here, the term has an existential meaning. It produces singularity. The surgically extracted nuance is intensified in writing and becomes the point where an altered subjectivity crystallises.

\section{Body Essay}

If, today, the fear of the powers of language and of the violence of categorising description or generalising subsumption is perhaps less urgent-because the forms of power have shifted and moved into the field of affirmations, of bodies and their norms, which are less conceptual and standardising than they are revivifying and regulating - then writing and artistic forms must answer to theory with other procedures. The subjectifying process of writing established in the wake of French theory, mainly in women's writing by such diverse authors as Hélène Cixous, Chris Kraus, or Avital Ronell, has been recently radicalised-most consequentially in Paul B. Preciado's Testo Junkie ${ }^{38}$ - by a way of writing that plays in two registers at the same time: the discursive, analytical, schooled-on-Foucault, genealogical reconstruction of a pharmacologically operating 'bio-power' and the excessively subjectifying writing of self-reporting, which borders on pornography. In a montage process which places theory, along with confessional literature and historical reconstruction, next to instructions for sexual practices, Preciado radicalises both erotic, sublimated reason and thought in figures. For Preciado, it takes the form of a theory tested on his own body and in published self-experiments. Here, the figures of thought literally become flesh, when hormones are taken and intervene in the physical form. 'Essayism' has also become more physically concrete in the self-experiment. Its open form becomes the uncertainty of an existence that subscribes to a way of "becoming" in which the categories 'male' and 'female' are no longer effective and in which the physical is realised as what Barthes may have phantasmagorically imagined to be neutralisation.

Translation from German by Allison Moseley.

37 Barthes (2005), The Neutral, pp. 105-106.

38 Paul Beatriz Preciado, Testo Junkie. Sex, Drugs, and Biopolitics in the Pharmacopornographic Era, translated by Bruce Benderson. New York, NY: Feminist Press, 2013. 


\section{Bibliography}

Auerbach, Erich, "Figura" (1938), in: Scenes from the Drama of European Literature, translated by Ralph Manheim. Minneapolis, MN: University of Minnesota Press, 1984, pp. $11-76$.

Barthes, Roland, "Lecture in Inauguration of the Chair of Literary Semiology. Collège de France, January 7, 1977," translated by Richard Howard, in: October 8 (1979), pp. $3^{-16}$.

Barthes, Roland, "F.B.," in: The Rustle of Language (1984), translated by Richard Howard. Oxford: Basil Blackwell, 1986, pp. 223-232.

Barthes, Roland, “Longtemps, je me suis couché de bonne heure . .., in: The Rustle of Language (1984), translated by Richard Howard. Oxford: Basil Blackwell, 1986, pp. 277-290.

Barthes, Roland, The Neutral: Lecture Course at the Collège de France (1977-1978) (2002), translated by Rosalind Krauss and Denis Hollier. New York, NY: Columbia University Press, 2005.

Barthes, Roland, The Preparation of the Novel: Lecture Courses and Seminars at the Collège de France (1978-1979 and 1979-1980) (2003), translated by Kate Briggs. New York, NY: Columbia University Press, 2011.

Barthes, Roland, How to Live Together. Novelistic Simulations of Some Everyday Spaces: Notes for a Lecture Course and Seminar at the Collège de France (1976-1977) (2002), translated by Kate Briggs. New York, NY: Columbia University Press, 2013.

Deleuze, Gilles, Nietzsche and Philosophy (1962), translated by Hugh Tomlinson. New York, NY: Columbia University Press, 1983.

Deleuze, Gilles, Proust and the Signs (1964), translated by Richard Howard. London: The Athlone Press, 2000.

Foucault, Michel, "The Order of Discourse” (1971), translated by Ian McLeod, in: Robert Young, ed., A Post-Structuralist Reader, Boston et al.: Routledge \& Kegan Paul, 1981, pp. $5^{1-78}$.

Ortheil, Hanns-Josef, "Nachwort," in: Roland Barthes, Variations sur l'écriture. Variationen über die Schrift (2002), translated by Hans-Horst Henschen. Mainz: DVB, 2006, pp. $195^{-217 .}$

Peters, Karin, "Einleitung: Pourquoi j'aime Barthes, oder: Philologie als Liebe," in: Angela Oster/Karin Peters, eds., Jenseits der Zeichen: Roland Barthes und die Widerspenstigkeit des Realen. Munich: Fink, 2012, pp. 11-31.

Preciado, Paul Beatriz, Testo Junkie. Sex, Drugs, and Biopolitics in the Pharmacopornographic Era (2008), translated by Bruce Benderson. New York, NY: Feminist Press, 2013.

Todorov, Tzvetan, "Der letzte Barthes" (1981), translated by Joseph Vogl, in: Hans-Horst Henschen, ed., Roland Barthes. Munich: Boer, 1988, pp. 129-137. 